\author{
Wojciech Soliński \\ Instytut Filologii Polskiej \\ Uniwersytet Wrocławski \\ e-mail: wojciech.solinski@uwr.edu.pl \\ ORCID: 0000-0001-8244-3101
}

\title{
Ateliery i plenery w prozie Bohumila Hrabala*
}

Dla Ernsta Cassirera czas i przestrzeń to ramy zamykające w sobie całą rzeczywistość. Szczególnego charakteru nabierają one w doświadczeniu człowieka. Miejscem spotkania pomiędzy światem ludzkim a zwierzęcym jest domena określona przez - urodzonego w Breslau, szwedzkiego z wyboru - myśliciela mianem „przestrzeni symbolicznej”. Cassirer dodaje przy tym, że tylko człowiek dochodzi drogą mozolnego procesu myślowego do pojęcia „przestrzeni abstrakcyjnej” ${ }^{1}$. Pisząc o procesie odtwarzania przestrzeni i stosunków przestrzennych, stwierdza, że:

Aby odtworzyć jakąś rzecz nie wystarcza umieć manipulować nią w właściwy sposób i w celach praktycznych. Ażeby odkryć związki jakiegoś przedmiotu z innymi przedmiotami, musimy mieć o nim pewne ogólne pojęcie i rozważać go z różnych punktów widzenia. Musimy go umiejscowić i określić jego położenie w ogólnym układzie².

Odnosząc się do myśli Heraklita i Leibniza, Cassirer przypomina o, towarzyszącym zawsze pojęciu przestrzeni, czasie. Czas przeszły, teraźniejszy

\footnotetext{
* W tytule wyzyskuję specyfikę języka czeskiego, w którym słowo atelier występuje również $\mathrm{w}$ liczbie mnogiej.

1 E. Cassirer, Esej o człowieku. Wstęp do filozofii kultury, przeł. A. Staniewska, Warszawa 1971, s. $92-94$.

2 Tamże, s. 98.
} 
i przyszły stanowią w egzystencji ludzkiej całość nierozszczepialną na poszczególne elementy. Elementem sine qua non rozważań na temat czasoprzestrzeni jest pamięć, rescpective, przypomnienie, rozumiane jednak nie jako „proste powtórzenie”, ale jako „ponowne narodziny wydarzeń przeszłych”, implikujące "proces twórczy i konstruktywny" niepolegający tylko na gromadzeniu pojedynczych danych „,z naszych minionych doświadczeń", które należy „zebrać ponownie [...] zorganizować, zsyntetyzować, uczynić je ośrodkiem naszej myśli" 3 .

Po tym filozoficznie symbolicznym, czy symbolicznie filozoficznym, wprowadzeniu przyjdzie wyjaśnić, jak zostaną tu potraktowane dwa tytułowe, chociaż wcale nie podstawowe dla tych rozważań, pojęcia: „atelier" i „plener", które nie pochodzą przecież wprost z literaturoznawczego instrumentarium. Przenikają doń ze świata sztuk plastycznych (szczególnie malarstwa), a z czasem, coraz częściej, także ze sztuki filmowej. Może warto przypomnieć, że atelier to najczęściej pracownia artysty (malarza, rzeźbiarza, fotografika), odpowiednio oświetlona światłem naturalnym lub sztucznym, wyposażona stosownie do rodzaju twórczości; atelier rozumiane jako „wnętrze" stanowi często temat dzieł malarskich ${ }^{4}$. Od czasów powstawania sztuki filmowej istotną rolę zaczęło odgrywać atelier filmowe, zwykle aranżowane w wytwórni filmowej.

Pojęciem "plener", również francuskiego pochodzenia, określa się malowanie na wolnym powietrzu, bezpośrednio z natury. Za inicjatorów tego typu malarstwa uchodzą przedstawiciele tzw. szkoły angielskiej. Szeroko rozpowszechnili je na początku wieku XIX impresjoniści. Z czasem weszło do programu kształcenia artystów. Współcześnie mianem plenerów nazywa się pobyty grup artystów w określonym miejscu/miejscowości poświęcone pracy twórczej. Odpowiednio na gruncie sztuki filmowej pojawiły się sceny plenerowe, kręcone w przestrzeni naturalnej, zwykle jednak na różne sposoby filmowo "naturalizowanej", zgodnie z wymaganiami scenariusza.

Oba pojęcia są tu, jak to wyraźnie widać, rozumiane bardzo szeroko, bez większej dbałości o terminologiczną precyzję. Odpowiednio ",atelierem” jest każde wnętrze, a „plenerem” każda przestrzeń na tzw. wolnym powietrzu, w których rozgrywa się akcja poszczególnych dzieł prozatorskich czeskiego

\footnotetext{
3 Tamże, s. 103-104, 106.

4 „Atelier"w tym rozumieniu pojawia się u Hrabala tekstach poświęconych jego wiernemu druhowi, grafikowi, malarzowi, wreszcie "czułemu barbarzyńcy", Vladimírowi Boudnikowi. Najsłynniejsze atelier fikcjonalne w prozie Hrabala to pracownia fotograficzna wuja ukochanej bohatera Pociagów pod specjalnym nadzorem, na zapleczu której przeżywa on swoją erotyczną klęskę, gorzko-ironicznie zwieńczoną następującym po niej alianckim nalotem bombowym, po którym z całej pracowni pozostaje tylko deska z reklamowym napisem „W 5 minut gotowe!”.
} 
pisarza. Dlatego warto odwołać się także do kategorii miejsca ${ }^{5}$, zawsze wtedy, kiedy nie można posłużyć się pojęciami tytułowymi, które mają wskazywać także na "organiczne" związki prozy Hrabala z filmem fabularnym, polegające - najogólniej rzecz ujmując - nie tylko na tym, że jego literackie formy narracyjne (krótsze i dłuższe) są niemal natychmiast adaptowane na filmy fabularne ( $\mathrm{i}$ to, $\mathrm{z}$ dwoma bodaj wyjątkami, realizowane następnie przez tego samego reżysera, przy udziale pisarza jako współautora scenariusza i nierzadko aktora epizodycznego). Ten związek ze sztuką filmową byłby niepełny bez wskazania na metodę twórczą pisarza, która kształtuje się w rezultacie tego, co, podążając za czeskim krytykiem, określiłem kiedyś jako myślenie obrazem filmowym i pisanie poetycką prozą. Jaroslav Kladiva ujmował to tak:

Podczas swoich wędrówek [Hrabal] chłonie wszystko oczami malarza, reżysera filmowego i kamerzysty. Jednakże, kiedy pisze wówczas posługuje się metodami, które są mu - jako pisarzowi właściwe. $\mathrm{W}$ błędzie są ci, którzy sądzą, że Hrabal tworzy w zasadzie w podobnym stylu jak reżyser filmowy czy też plastyk. Często też pisano, że Hrabal jest mistrzem ujęć filmowych, iż potrafi naświetlić $\mathrm{w}$ zbliżeniu detal, podejść $\mathrm{z}$ dystansem do całości ujęcia [...]. Jednakże sama zdolność plastycznego ujęcia czy też filmowego widzenia nie determinuje jeszcze adekwatnych środków wyrazu. W specyficznej metodzie Hrabala mieszają się wizualne, imaginacyjne oraz (przede wszystkim) językowe elementy wrażliwości i fantazji, tworząc wzajemne napięcie o swoistym literackim charakterze ${ }^{6}$.

Reżyser niemal wszystkich adaptacji prozy Hrabala tę filmową właściwość charakteryzował następująco:

Przeczytajcie parę stron Hrabala, a zobaczycie film [...]. Hrabal ma w swoich tekstach ukryte gotowe obrazy. Ale trzeba nad nimi popracować [...]. To, co napisze, trzeba rozebrać na czynniki pierwsze i znowu złożyć ${ }^{7}$.

A należy też pamiętać, że Hrabal był zdeklarowanym kinomanem chodzącym do kina w jego złotych latach, znacznie wyprzedzających rozkwit

\footnotetext{
5 Por. Y-F. Tuan, Przestrzeń i miejsce, przeł. A. Morawińska, Warszawa 1987. Dla autora tej pracy każda zamknięta i uczłowieczona przestrzeń staje się miejscem, w którym inaczej niż w przestrzeni panuje spokój utrwalonych wartości. Człowiek potrzebuje zarówno miejsca, jak i przestrzeni. Życie ludzkie to rodzaj oscylacji między bezpiecznym azylem a przygodą, między przywiązaniem a wolnością.

6 J. Kladiva, Język prozy Bohumila Hrabala, przeł. J. Stachowski, "Literatura na Świecie” 1991, s. 310 .

7 Cyt. za: M. Robert, Perełki i skowronki. Adaptacje filmowe prozy Bohumila Hrabala, Łódź 2014, s. 200-201.
} 
czeskiej filmowej Nowej Fali, do której należą nie tylko arcydzielne, nagrodzone Oskarem, Pociagi pod specjalnym nadzorem ${ }^{8}$.

Organiczną, chce się rzec, biograficzność całej prozy Hrabala wolno, jak się zdaje, rozpatrywać w duchu autobiografii Goethego - Dichtung und Warheit (Zmyślenie i prawda), czyli poprzez nadanie odosobnionym i rozproszonym faktom kształtu poetyckiego, to znaczy symbolicznego. Analiza tej prozy prowadzi bowiem do konstatacji, że - jak to ujął Ibsen - „być poetą to znaczy być swoim własnym sędzią". Hrabal staje się takim właśnie sędzią (nawet wtedy, a może przede wszystkim, wtedy), kiedy samoosądza się słowami swojej żony, którą czyni narratorką tryptyku Wesela w domu, Vita nuova, Przerwy [Svatby $v$ domě, Vita nuova, Proluky]. W utworach tych znajdujemy raczej elementy samowiedzy i samokrytyki, nie zaś „nagany, usprawiedliwienia ani potępienia, ale nowe i głębsze zrozumienie, nową interpretację osobistego życia poety" 9 .

Problem przestrzeni artystycznej jawi się w myśli Jurija Łotmana w następstwie pojmowania dzieła sztuki jako $\mathrm{w}$ pewien sposób wyodrębnionej przestrzeni, która w swej skończoności obrazuje nieskończony obiekt - zewnętrzny $\mathrm{W}$ stosunku do dzieła świat ${ }^{10}$. W ten sposób „struktura przestrzeni tekstu artystycznego staje się modelem Wszechświata, a wewnętrzna syntagmatyka elementów wewnątrz tekstu - językiem modelowania przestrzennego"11.

Taki model ma zawsze w strukturze tekstu artystycznego jakoś określone centrum, podobnie jak mapy kreślono zawsze z pewnego punktu widzenia. Tym miejscem centralnym jest w prozie Hrabala jego Europa Środkowa, o której będzie jeszcze mowa poniżej. A samo modelowanie odbywa się poprzez wykorzystywanie podstawowych środków rozumienia rzeczywistości np.: wysoki - niski, prawy - lewy, bliski - daleki, otwarty - zamknięty, które służą do budowy modeli kulturowych o zgoła nie przestrzennej treści, nadających sens otaczającemu światu, bo znaczących, np.: wartościowy - bezwartościowy, dobry - zły, swój - obcy, śmiertelny - nieśmiertelny itp. ${ }^{12}$

8 Por. W. Soliński, Film, kino i Hrabalowy star system, w: tegoż, Bohumila Hrabala sprawa polska (i inne sprawy), Wrocław 2013, s. 131-145.

${ }_{9}$ Cassirer precyzuje, że jego uwagi nie dotyczą jedynie poezji, ale możliwe są w każdym innym środku wyrazu artystycznego. Por. E. Cassirer, Esej o człowieku, przeł. A. Staniewska, Warszawa 1971, s. 106-107.

10 J. Łotman, Problem przestrzeni artystycznej, w: tegoż, Struktura tekstu artystycznego, przeł. A. Tanalska, Warszawa 1984, s. 310.

11 Tamże, s. 311.

12 Tamże, s. 311-312. 
Przy czym należy mieć na uwadze to, że Hrabalowe oscylacje między prawdą a zmyśleniem działają tak, że niemal wszystkie "ateliery" i plenery ciągle można zobaczyć, chociaż wszystkie one są już takie same, a jeden z najbardziej „twórczych” domów pisarza, ciemna klitka w podwórku kamienicy numer 24 przy ulicy Na Grobli, na plebejskiej, cygańskiej, praskiej Libni, istnieje już tylko $w$ jego tekstach. Nie istnieje przecież nawet zatrzymany przez autora w czasie Nymburk, ani wyobrażony na podstawie lektur Schulzowy Drohobycz ${ }^{13}$.

\section{Ateliery (domy i knajpy)}

Jeśli uznać twórczość Hrabala za, modelowany przez niego samego, przekaz obrazujący drogę życiową człowieka od początku do końca, zgodnie z formułą Maryny Cwietajewej: „Żył jak człowiek i umarł jako poeta”, to można też przyjąć za Łotmanem, że początek i koniec drogi życiowej tego mistrza prozy odpowiadają modelowi poety ${ }^{14}$. Najdobitniej określa to stosunek emocjonalny Hrabala do licznych domów/mieszkań/pokojów, w jakich przyszło mu mieszkać. Najistotniejsze są te związane bezpośrednio, rzadziej pośrednio, z aktywnością twórczą (z pełnieniem funkcji pisarza) nawet jeśli czuł się on w nich, jak sam mawiał, „pisarzem w likwidacji”. Nie będzie wielkim ryzykiem uznanie za najważniejsze więcej niż skromnego mieszkania w podwórzu kamienicy przy ulicy Na Grobli 24 w praskiej dzielnicy Libeń. Gdyby pokusić się o listę "twórczych” domów Hrabala, to ostatnie na niej miejsce zajęłoby wyposażone we wszelkie wygody mieszkanie w bloku na praskich Sokolnikach. Chociaż, biorąc pod uwagę inne jego miejsca zamieszkania, można przypuszczać, że pewnie tylko we wczesnym dzieciństwie, w ",rodzinnym” domu dziadków Kilianów, na stromej ulicy Balbina w Brnie-Židenicach, dopiero zaczynał być poetą. Gdyby emocjonalne nacechowanie domów Hrabala (dom dziadków; dom w Polnej; mieszkanie w nymburskim browarze; willa „Hrabalka”; ciemna klitka na Grobli „wieczności”; „chata” w kerskim lesie; wreszcie spółdzielcze mieszkanie w bloku na Sokolnikach) postarać się oddać za pomocą wykresu, byłby to garb, na którego szczycie znalazłyby się: ciemny pokój Na Grobli i chata w kerskich lasach.

13 Nie ma żadnych dowodów pozwalających stwierdzić, czy pisarz mógł skonfrontować ten obraz z wyobrażeniem tego miasteczka, w którym czas się przecież również nie zatrzymał, w filmie Wojciecha Jerzego Hasa Sanatorium pod Klepsydra (1973).

14 Należy pamiętać, że Hrabal bodaj nigdy nie przestał „być poetą (przeklętym)” mimo tego, że to nie wiersze zapewniły mu literacki sukces. 
Do twórczości Hrabala można bez ryzyka zastosować kategorie początku i końca zaproponowane przez Jurija Łotmana, kiedy to owe pojęcia przypisuje się przekazom opisującym drogę życiową człowieka ${ }^{15}$. W całej niemal prozie Hrabala, a najintensywniej w eseju Kim jestem [Kdo jsem], obecny jest motyw nieuchronnego samobójczego końca jako autodefenestracji.

Żona pisarza, obsadzona przez niego w roli narratorki trylogii Wesela $w$ domu, Vita nuova i Przerwy, opisuje życie swojego męża jako wieczną oscylację pomiędzy knajpą a domem. Przy czym piwna knajpa była dla Hrabala m.in. ważnym miejscem pracy twórczej, bo to właśnie tam gromadził materiał stanowiący podstawę jego - szczególnie wczesnych - utworów, które sam uważał za „zapisane”, nie zaś za „napisane”, uznawał się bowiem wtedy za „zapisywacza”, nie zaś za „pisarza”. Czym była dla niego, nie zawsze dobrze pachnąca, piwiarnia opisał w najpełniej w szkicu zatytułowanym Czym jest knajpa [Co to je hospoda], który zaczyna się tak:

Czym jest knajpa, knajpa w moim rozumieniu? To pomieszczenie, które wprawdzie ma pewne reguły, pewien rytuał, pewne zastygłe dogmaty, ale równocześnie jest pomieszczeniem, gdzie oprócz game goście nie tylko cieszą się, ale pod wrażeniem chwili oddają się play, zabawie, zabawom dorosłych dzieci. Gospoda jest miejscem obrony przed stereotypem, a nawet takim miejscem, gdzie ci najzwyczajniejsi ludzie potrafią improwizować, potrafią poddać się rytmowi improwizacji, imaginacji...

a kończy w sposób następujący:

Czasem tchórzostwo jest największym męstwem, niewiara największą wiarą, ostrożność największą zadziornością. Zadowolenie się małym jest największą cnotą. Spalenie świata $\mathrm{w}$ rewolucji i przemocy jest zbrodnią nie przeciw ludzkości, lecz przeciw knajpce, tej najgłupszej, najbanalniejszej knajpce ${ }^{16}$.

Niewiele jest tekstów Hrabala, w których brakowałoby gospody, ale są przecież takie (jak np. Święto przebiśniegu [Slavnosti sněženek]), gdzie knajpa gra rolę pierwszoplanową. W dusznej atmosferze tak zwanej komunistycznej normalizacji po zduszeniu "praskiej wiosny” 1968 roku, to jedyne miejsce w miarę swobodnych kontaktów społecznych w klimacie wyjątkowej w swoim rodzaju przestrzeni sakralnej, jednoczącej wszystkich mieszkań-

15 Por. J. Łotman, O modelującym znaczeniu "końca” $i$ "poczatku” w przekazach artystycznych. Tezy, przeł. J. Faryno, w: Semiotyka kultury, wybór i opracowanie E. Janus i M.R. Mayenowa, Warszawa 1977, s. 349.

16 B. Hrabal, Czym jest knajpa, w: tegoż, Piękna rupieciarnia, przeł. J. Stachowski, Wołowiec 2006, s. 143 i 152. 
ców kerskiego lasu w zbiorowym rytuale uczty. Dzieje się także dlatego, że ukryta w kerskich lasach restauracja „Leśna” ${ }^{17}$, to miejsce, w którym - jak pisał Caillois - „nie ma ani władzy, ani prawa” ${ }^{18}$.

Do knajpy z piwnicznego piekła Zbyt głośnej samotności (Př́liš hlučná samota) ucieka bohater tego utworu Hańtia, by znaleźć się w przestrzeni granicznej między sacrum a profanum. To w takich miejscach, związanych z doczesnością i pospolitością codziennego życia, kultywuje się rodzaj sacrum zeświecczonego czy też kanonizowanego profanum, zawsze się owej codzienności i pospolitości życia w „racjonalnym” czasie i przestrzeni przeciwstawiającego ${ }^{19}$.

W tym miejscu trzeba koniecznie dodać, że Jiří Menzel w każdej adaptacji, a szczególnie w Święcie przebiśniegu, znaczenie i rytuały tego miejsca wspaniale uwydatnia.

\section{Plenery (miasta i lasy)}

Przestrzeń w prozie Hrabala, szczególnie tej składającej się na „tryptyk” Městečko u vody [Miasteczko nad woda], czyli w Postrzyżynach, Takiej pięknej żałobie, Skarbach świata całego [Postřižiny, Krasosmutněni, Harlekýnovy milióny], ale też w Miasteczku, w którym czas się zatrzymat [Městečko, kde se zastavil čas] kształtowana jest nie bez wpływu Sklepów cynamonowych Schulza ${ }^{20}$. Istotą tego „zapatrzenia się" czeskiego pisarza jest dziecięcy świat marzeń, fantazji i urojeń narratora-bohatera prozy autora z Drohobycza. Ale też poza Nymburkiem to zapewne właśnie Drohobycz, nigdy przez Hrabala nie zobaczony, ale wielokrotnie przez niego wyobrażany, zajmuje szczególne miejsce wśród ważnych dla niego miast jego Europy Środkowej. A to wspomniane wyżej zapatrzenie najdobitniej zdaje się potwierdzać swoiste motto do Takiej pięknej żałoby:

Myślę, że im dłużej idzie człowiek przez życie, tym bardziej odczuwa potrzebę powrotu do swojego dzieciństwa, tym większe odczuwa pragnienie powrotu w głąb wyobraźni chłopca, do jego postaci, by urzeczywistnić to, o czym jako dziecko myślał, o czym marzył. Zamykając krąg swoich cykli, zatrzymałem

\footnotetext{
17 W dosłownym przekładzie na język polski powinna to być "Gajówka".

18 Por. R. Caillois, Człowiek i sacrum, przeł. A. Tatarkiewicz, E. Burska, Warszawa 1995, s. 57.

19 M. Madurowicz, Sfera sacrum w przestrzeni miejskiej Warszawy, Warszawa 2002, s. 65.

20 Fascynację prozą Schulza czeski autor podkreśla wielokrotnie. Tu odsyłam do rozdziału Drohobycz Hrabala w: W. Soliński, Bohumila Hrabala sprawa polska (i inne sprawy), Wrocław 2013, s. 24-27.
} 
się przy tych kilku latach szkoły powszechnej, kiedy umiałem latać nie znając zasad lotu, kiedy potrafiłem myśleć dokładniej niż później, kiedy nie rozstawałem się z książkami i wszystko stawiałem na wykształcenie.

I tak oto $\mathrm{w}$ tych opowiadaniach zatrzymałem piękne obrazy, które nie starzeją się wraz ze mną; w książce tej pozostaję niezmiennie chłopczykiem w marynarskim ubranku, z tornistrem pełnym książek i zeszytów na plecach, wciąż jednak pogrążonym w szczelnym dzwonie świadomej nieświadomości, wciąż wybiegającym naprzeciw tajemnicy i zdziwieniu wywołanemu osłupieniem tym, co się wokół niego dzieje.

I czując obumieranie ciała stwierdziłem, iż ten chłopiec we mnie jest nie tylko moim domowym korepetytorem, nie tylko światłem w gęstniejącym zmierzchu, lecz także miarą wszystkich owych rzeczy, których nie dotyczy ani umieranie, ani śmierć ${ }^{21}$.

Realizm prozy Hrabala, który on sam określał mianem realizmu totalnego, nie zawsze polega na wiernym odtwarzaniu rzeczywistego wyglądu rzeczy lub zjawisk, szczególnie wtedy, kiedy ma się do czynienia z powrotem do dzieciństwa, z próbą odzyskania utraconego raju, do którego przecież nie ma już wstępu. Język takiej prozy nie uznaje granic między jawą a snem; jest bogaty, dynamiczny i dramatyczny, co pozwala autorowi na oddanie nieustannej płynności i zmienności świata. Nymburk śniony jest miasteczkiem, w którym czas się zatrzymał, w którym biło serce jego Europy Środkowej, w którym pisarz szczególnie upodobał sobie ulice znajdujące się na krańcach:

takie domki, małe wille odgrodzone od siebie ogródkami, secesyjne fasady, chodniki z ozdobnej kostki [...] w letnie dni, na ogół koło południa, w lipcu i sierpniu powietrze drżało i czułem się w Nymburku jak w Galicji [... $]^{22}$.

Tylko w niewielu miejscach ten jego widzialny Nymburk, z podwórkami i ogródkami, ,jakby je namalował malarz naiwny", pozostaje tym prawdziwym, chociaż już niewidzialnym, Nymburkiem, istniejącym tylko pod "zamkniętymi powiekami". Ponieważ w Nymburku, chce się rzec, totalnie i boleśnie realistycznym, czas płynie nieubłagalnie, Hrabal pisze o nim tak:

Już go skreśliłem, ten Nymburk jaki jest teraz. Kiedy tam przyjeżdżam, mam wrażenie, jakby przed paroma dniami przejechała tamtędy walcząca armia i zostawiła za sobą zrujnowane place, ulice [...]. To boli [...]. Niech o tym Nymburku piszą młodzi, niech spróbują uchwycić istotę tego nowego Nymburka, ja już nie mam do niego klucza $[\ldots]^{23}$.

\footnotetext{
21 B. Hrabal, Taka piękna żałoba, przeł. A. Czcibor-Piotrowski, Izabelin 1997, s. 5.

22 B. Hrabal, Piękna rupieciarnia, przeł. A. Kaczorowski, Wołowiec 2006, s. 89.

23 Tamże, s. 92-93.
} 
Więcej jest powodów utraty klucza do miasteczka, gdzie stanął czas, ale tylko na chwilę, jak ten niemiecki czołg, który próbował zatrzymać siłą sugestii dziadek bohatera Pociagów pod specjalnym nadzorem [Ostře sledované vlaky]. Wejście do miasteczka oddziałów Armii Czerwonej zapoczątkowało ciąg wydarzeń, które wstrząsnęły do głębi Nymburkiem jako „starą rupieciarnią" 24. $\mathrm{Z}$ tych wydarzeń bodaj największe wrażenie robi „defenestracja drewnianych Chrystusów", zgromadzonych na strychu miejskiego gimnazjum, dokonana przez gromadkę ludzi śpiewających Międzynarodówkę. Ten obraz to, zdaniem pisarza, obraz historii nie tylko tego miasteczka, ale i całego narodu, tego wszystkiego, co nazywało się Europą Środkową...

Nie pozostaje zatem nic innego, jak się z tym pogodzić, szczególnie kiedy się pamięta, że Hrabal ten świat wyłącznie opisuje, bez ambicji zmieniania go, więc cieszy się, że nauczył się patrzeć na rzeczy, „których nie tylko ja, ale każdy człowiek się boi", bo w jego mniemaniu „istota nie tylko filozofii, ale i literatury, to umieć patrzeć obojętnie na rzeczy, przy których włosy stają dęba" 25 .

\section{Inne miejsca}

Można zgodzić się ze zdaniem Seneki, wykorzystanym przez Monikę Zgustovą w tytule jednego z rozdziałów biografii Hrabala: Cały świat jest mojq ojczyzną ${ }^{26}$. Gdyby do pisarza przystosować słynną autolokalizację z okładki kajetu Stephena Dedalusa, to wyglądałaby ona jakoś tak: Nymburk, Kersko Praga, Morawy, Europa Środkowa, Świat. Chociaż ta sama Monika Zgustová podkreśla to, o czym wielokrotnie mówił i pisał sam Hrabal, że, mimo licznych wyjazdów zagranicznych, w tym zaoceanicznych, za granicą czuł się obcy, i pewnie dlatego zawsze $\mathrm{z}$ tych podróży wracał. A może także $\mathrm{z}$ tej przyczyny, że ów świat był dla niego do szaleństwa piękny, nie dlatego, że taki jest, ale dlatego, że takim go postrzegał rzeczywisty, chociaż w znacznej mierze przez niego wykreowany, stryj Pepin ${ }^{27}$.

Z wyżej wymienionego szeregu „miejsc innych" warto przez chwilę zadumać się nad Hrabalowskim konceptem Europy Środkowej, pamiętając przy tym, że wspomniany tu już wcześniej Drohobycz pisarza to jeden z waż-

\footnotetext{
24 Tytuł Piękna rupieciarnia nadał polskiemu przekładowi A. Kaczorowski. W oryginale nosi on tytuł Rozhovor sám se sebou [Rozmowa z samym soba].

25 Por. B. Hrabal, Piękna rupieciarnia, s. 96-99.

26 Por. M. Zgustová, Bohumil Hrabal, przeł. Z. Tarajło-Lipowska, Wrocław 2000, s. 157.

27 Zapewne nie przypadkiem to zdanie polecił wydrukować na nekrologu stryja Pepina.
} 
niejszych punktów na jego mapie tego obszaru. Jego Europa Środkowa to najczęściej przestrzeń obejmująca Wiedeń, Budapeszt, Pragę, Brno, Kraków, czyli miasta, które w granicach monarchii austro-węgierskiej leżały blisko siebie. Pisał o nich jako o polikulturowych centrach, w których „wartością dodatkową" jest owa wielokulturowość. Ale miejsc takich znajdziemy na jego mapie więcej, bo był tam także Lwów, Przemyśl, Mikulov, Budziejowice oraz - a może przede wszystkim - właśnie Drohobycz, do którego zaprowadził go Bruno Schulz w Sklepach cynamonowych. Ten Drohobycz, w którym nigdy nie był, ale w którym chciałby mieszkać, do którego się przeprowadził - jak sam twierdził w Rozmowie $z$ samych sobq - po pierwszej lekturze Sklepów. Europa Środkowa Hrabala była także w znacznym stopniu taka, jaką oglądał ją podczas pierwszej wojny światowej dzielny wojak, stryj Pepin, stanowiący konglomerat żołnierza-samochwały z baronem Münchhausenem. Wszakże sercem Hrabalowej Europy Środkowej był jednak Nymburk, ale tylko ten, w którym czas się zatrzymał, w którym pisarz czuł się jak w już tu wspominanej Galicji, gdzie uliczki i rynki żydowskich miasteczek przypominały mu Drohobycz, znany z prozy Schulza. A pisał o tym między innymi tak:

kiedy podróżowałem po Węgrzech, przejeżdżałem przez takie właśnie miasteczka o identycznej strukturze jak te na Śląsku i Morawach, dlatego nie tylko na Węgrzech, ale i w Polsce już jako student czułem się swojsko, teraz także mam poczucie ogromnej bliskości z Węgrami i Polakami, i Żydami, chociaż z zewnątrz wszystko wygląda inaczej... Ale wystarczy przeczytać jedną trzecią nazwisk $\mathrm{w}$ książce telefonicznej, żeby spojrzeć na to $\mathrm{w}$ inny sposób...28.

Pamiętając o losach miasteczka, gdzie czas się jednak nie zatrzymał, nietrudno odnieść to do końca Hrabalowej Europy Środkowej, która niezmieniona pozostała tylko w opowieściach stryja Pepina (zasadniczo w granicach c. k. Galicji), a której centrum stanowił Nymburk. Jej pełniejszy obraz jawił się w imaginacyjnych wyprawach pisarza do Drohobycza, tego najpiękniejszego miasta na świecie, "którego już nie ma, a więc chyba właśnie dlatego”, a do którego zaprowadził go Bruno Schulz W sklepach cynamonowych. Ten Bruno Schulz, „,którego jakiś niemiecki żołnierz [...] zastrzelił na ulicy tylko dlatego, że był Żydem" 29 .

I to do tak wyobrażonej, wzbogaconej o Drohobycz, Europy Środkowej przeprowadził się pisarz i mieszkał tam póki żył, chociaż nigdy w nim

28 B. Hrabal, Piękna rupieciarnia, s. 89-90.

29 Tamże, s. 92. 
nie był, „ale co z tego? Fikcja bywa doskonalsza i prawdziwsza niż rzeczywistość" 30 .

Tak oto $\mathrm{w}$ prozie czeskiego mistrza realizuje się przejście $\mathrm{z}$ przestrzeni symbolicznej, poprzez przestrzeń abstrakcyjną, do totalnie realistycznej przestrzeni artystycznej ${ }^{31}$.

\section{Bibliografia}

Hrabal Bohumil (1997), Taka piękna żałoba, przeł. A. Czcibor-Piotrowski, Izabelin: Świat Literacki.

Hrabal Bohumil (2006), Piękna rupieciarnia, przeł. J. Stachowski, Wołowiec: Wydawnictwo Czarne.

Caillois Roger (1995), Człowiek i sacrum, przeł. A. Tatarkiewicz, E. Burska, Warszawa: Oficyna Wydawnicza Volumen.

Cassirer Ernst (1971), Ludzki świat czasu i przestrzeni, w: E. Cassirer, Esej o człowieku. Wstęp do filozofii kultury, przeł. A. Staniewska, Warszawa: Czytelnik, s. 92-111.

Kladiva Jaroslav (1991), Język prozy Bohumila Hrabala, przeł. J. Stachowski, „Literatura na Świecie", nr 1, s. 308-319.

Łotman Jurij (1977), O modelujacym znaczeniu "końca" $i$ "początku” w przekazach artystycznych (Tezy), przeł. J. Faryno, w: Semiotyka kultury, red. E. Janus i M. R. Mayenowa, Warszawa: Państwowy Instytut Wydawniczy, s. 344-349.

Łotman Jurij (1984), Problem przestrzeni artystycznej, w: J. Łotman, Struktura tekstu artystycznego, przeł. A. Tanalska, Warszawa: Państwowy Instytut Wydawniczy, s. 310-329.

Madurowicz Mikołaj (2002), Sfera sacrum w przestrzeni miejskiej Warszawy, Warszawa: Wydawnictwo Akademckie Dialog.

Robert Maciej (2014), Perełki i skowronki. Adaptacje filmowe prozy Bohumila Hrabala, Łódź: Wydawnictwo Uniwersytetu Łódzkiego.

Soliński Wojciech (2013), Bohumila Hrabala sprawa polska (i inne sprawy), Wrocław: Oficyna Wydawnicza ATUT.

Tuan Yi-Fu (1987), Przestrzeń i miejsce, przeł. A. Morawińska, Warszawa: Państwowy Instytut Wydawniczy.

Zgustová Monika (2000), Bohumil Hrabal, przeł. Z. Tarajło-Lipowska, Wrocław: Wydawnictwo Dolnośląskie.

\footnotetext{
30 Tamże.

31 Pojęcie totalnego realizmu przejął Hrabal od Egona Bondy'iego [prawdziwe nazwisko Zbyněk Fišer], którego cykl poetycki, pod tym właśnie tytułem, wpłynął znacząco na jego prozę.
} 


\title{
Ateliers and en plein-airs in the Prose of Bohumil Hrabal
}

\begin{abstract}
The article analyzes the emotional aspect of autobiographical places in the works of Bohumil Hrabal. Its author observes that both the short and the long prosaic forms by the Czech writer are often set in the space stretching between ateliers of pubs and en plein-airs of Nymburk on the Elbe River ("the town on water"), forests of Kersko, and the degraded smelter plant Krásná Poldi in Kladno. The list of Hrabal's locations does not end here and also includes the "borderland areas", such as the control room and platforms of the railway station in Kostomlaty nad Labem; the basement of the wastepaper warehouse in Spalona Street in Prague (and pubs nearby); the author's flat (which had neither windows nor a toilet) located at $24 \mathrm{Na}$ Hrázi (Věčnosti) Street and many other streets leading directly to the Svět pub Special attention is also given to a place that the author had never visited - Drohobych, but got to know through the prose of Bruno Schulz.
\end{abstract}

Keywords: atelier, en plein-airs, autobiographical locations, symbolic space, artistic space 